\title{
STUDI WAKTU PERJALANAN DAN TUNDAAN DENGAN APLIKASI VISSIM PADA RUAS JALAN A.H. NASUTION
}

\author{
Mangaramot Justisiano Pakpahan ${ }^{[1]}$, Budi Hartanto Susilo ${ }^{[2]}$ \\ ${ }^{[1]}$ Alumni Program Studi S-1 Teknik Sipil, Fakultas Teknik, Universitas Kristen Maranatha \\ ${ }^{[2]}$ Guru Besar Program Studi S-1 Teknik Sipil, Fakultas Teknik, Universitas Kristen Maranatha \\ Jalan Prof. Drg. Suria Sumantri No. 65, Bandung 40164 \\ Email:mangaramotjustisiano@rocketmail.com, budiharsus@yahoo.com
}

\begin{abstract}
ABSTRAK
Jalan A.H Nasution merupakan salah satu jalan arteri primer yang menghubungkan Cileunyi menuju Bandung Timur yang merupakan salah satu wilayah pilihan masyarakat Kota Bandung untuk bermukim. Oleh karenanya setiap jam sibuk sering terjadi kemacaten. Tujuan penelitian ini untuk mengidentifikasi waktu perjalanan pada ruas Jalan A.H Nasution, mengevaluasi setiap simpang yang menjadi salah satu sumber tundaan, dan menyampaikan solusi alternatif menggunakan aplikasi PTV Vissim. Ruas jalan yang ditinjau dari Simpang A.H. Nasution - Ahmad Yani sampai Ditbintekjatan (Direktorat Bina Teknik Jalan dan Jembatan). Pengambilan data pada hari Senin, 9 Maret 2020, pukul 06 - 07. Analisis waktu perjalanan dan tundaan kondisi eksisting ruas Jalan A.H Nasution dari Barat menuju Timur memiliki tingkat pelayanan F, waktu perjalanan 22 menit 10 detik dengan tundaan 410 detik. Dari Timur menuju Barat memiliki tingkat pelayanan F, waktu perjalanan 23 menit 47 detik dengan tundaan 345 detik. Perbaikan dengan cara pelebaran ruas lajur pada Sta $(0+000)$ - Sta $(0+500)$ dan larangan belok kanan pada setiap simpang pada ruas yang ditinjau, ruas jalan A.H Nasution dari Barat menuju Timur memiliki tingkat pelayanan C dengan waktu perjalanan lebih cepat dan tundaan lebih singkat. Arah Timur menuju Barat memiliki tingkat pelayanan D dengan waktu perjalanan lebih cepat dan tundaan lebih singkat.
\end{abstract}

Kata kunci: Ruas jalan, Studi waktu perjalanan, Tingkat pelayanan, Tundaan, Vissim.

\begin{abstract}
A.H. Nasution street is one of the primary arterial roads that connect Cileunyi to East Bandung, one of the favorite areas that chosen by people at Bandung to settle, therefore during rush hour there is congestion at A.H. Nasution street. The goal of this research is to identify vehicle travel time on A.H. Nasution Street, evaluate each intersection that is one of the sources of delays and provide alternative solutions using PTV Vissim. The sections that reviewed from the A.H. Nasution-Ahmad Yani Intersection until Ditbintekjatan, (Direktorat Bina Teknik Jalan dan Jembatan). Data collection on Monday, $9^{\text {th }}$ March 2020 at 06.00 am - 07.00 am. The existing analysis on A.H. Nasution street from west to east has LoS F with vehicle travel time 22 minutes 10 seconds and delay of 410 seconds, while from east to west has LoS F with vehicle travel time 23 minutes 47 seconds and delay of 345 seconds. If repairs are made by widening the lane at Sta $(0+000)-S t a(0+500)$ and the prohibition of turning right at each unsignalized intersection on the section that reviewed, the A.H. Nasution street from west to east has a LoS C, while from east to west has a LoS D, both with vehicle travel time faster and shorter delay.
\end{abstract}

Keywords: Sections, Travel time, Level of service, Delay, Vissim. 


\section{PENDAHULUAN}

\subsection{Latar Belakang}

Jalan A.H. Nasution merupakan jalan yang menghubungkan wilayah Bandung Timur menuju pusat kota yang merupakan salah satu wilayah pilihan masyarakat kota Bandung untuk bermukim, oleh karena itu setiap jam sibuk terutama pada pagi dan sore hari terjadi kemacetan. Ruas jalan dari Ditbintekjatan menuju Simpang A.H. Nasution Ahmad Yani, pada pagi hari sering terjadi kemacetan dibeberapa titik diantaranya Simpang Arcamanik - A.H. Nasution, Simpang Pasir Impun - A.H. Nasution, Simpang Pacuan Kuda - A.H. Nasution, RS Hermina, Simpang Cikadut - A.H. Nasution dan Terminal Cicaheum. Dengan banyaknya kemacetan atau tundaan, waktu perjalanan dari Ditbintekjatan hingga Simpang Ahmad Yani - A.H. Nasution menjadi cukup lama.

Studi waktu perjalanan dan tundaan mempelajari kecepatan perjalanan atau waktu yang diperlukan sebuah kendaraan untuk melewati sebuah jalan dengan memperhitungkan seluruh waktu perjalanan termasuk tundaan diluar waktu istirahat serta waktu dalam memperbaiki kerusakan kendaraan. Lama waktu perjalanan sangat mempengaruhi biaya perjalanan, seperti jumlah pemakaian bahan bakar, biaya operasional kendaraan, dan mempengaruhi tingkat polusi yang dihasilkan oleh kendaraan. Waktu perjalanan dan tundaan juga dapat membuktikan tingkat kemacetan jalan serta kemampuan layan atau operasional jalan tersebut.

Kemajuan teknologi sangat membantu dalam penyelesaian permasalahan lalu lintas, salah satu nya adalah aplikasi Vissim. Vissim adalah aplikasi pemodelan yang diciptakan oleh Planung Transport Verkehr (PTV). Vissim memerlukan data seperti volume lalu lintas, geometri jalan, kecepatan, dan dapat menghitung tingkat kemacetan serta melakukan penyelesaian permasalahan lalu lintas dengan melakukan pemodelan pada aplikasi tersebut. Vissim juga merupakan aplikasi pemodelan mikrosimulasi yang artinya menjadikan tiap kendaraan sebagai sebuah individu yang bergerak secara kesatuan dan juga melihat hingga parameter terkecil seperti driving behaviour.

\subsection{Tujuan Penelitian}

1. mengidentifikasi waktu perjalanan dan tundaan termasuk volume lalu lintas pada ruas Jalan A.H. Nasution;

2. menentukan solusi kemacetan ruas jalan A.H. Nasution;

3. mengevaluasi solusi yang ditetapkan pada ruas jalan A.H. Nasution. 


\subsection{Ruang Lingkup Penelitian}

1. ditinjau ruas jalan dari Simpang A.H Nasution - Ahmad Yani sampai Puslitbang Jalan dan Jembatan (Ditbintekjatan);

2. survei lapangan terdiri dari: survei geometri, survei volume kendaraan, survei kecepatan, survei arus bebas, survei waktu perjalanan dan tundaan menggunakan metode mobil pengamat bergerak (Moving Car Observer Method);

3. survei kecepatan menggunakan metode kecepatan sesaat (Spot Speed);

4. jenis kendaraan yang dihitung: sepeda motor (MC), kendaraan ringan (LV), kendaraan berat (HV), dan kendaraan tak bermotor (UM);

5. pengambilan data secara langsung pada Senin, 9 Maret 2020 pukul 06.00 - 07.00;

6. analisis waktu perjalanan dan tundaan pada ruas jalan Simpang A.H Nasution - Ahmad Yani sampai Ditbintekjatan saat kondisi eksisting serta pemodelan solusi menggunakan software Vissim.

\subsection{Metode Penelitian}

\subsubsection{Lokasi Penelitian}

Lokasi penelitian pada ruas Jalan A.H. Nasution yang dimulai dari Simpang Ahmad Yani - A.H Nasution hingga Puslitbang Jalan dan Jembatan (Ditbintekjatan) sepanjang $3,55 \mathrm{~km}$.

Geometri memiliki 2 karakteristik: Sta $(0+000)$ yang dimulai pada Simpang Ahmad Yani - A.H. Nasution hingga Sta $(0+500)$ merupakan jalan 4/2 D dengan lebar efektif setiap jalur rata-rata 7,5 m sedangkan Sta $(0+500)$ sampai titik akhir Ditbintekjatan Sta (3+550) merupakan jalan 4/2 UD dengan lebar efektif setiap jalur $6 \mathrm{~m}$. Peta citra satelit lokasi penelitian dapat dilihat pada Gambar 1.



Gambar 1. Peta Citra Satelit Lokasi Penelitian 


\subsubsection{Teknik Pengumpulan Data}

Metode pengumpulan data dilakukan dengan dua cara yaitu: data observasi dan data sekunder. Data tersebut diolah dan dianalisis untuk menghasilkan waktu perjalanan ruas Jalan A.H. Nasution serta kondisi yang terjadi setelah dilakukan beberapa perubahan dengan aplikasi Vissim.

Data observasi diperoleh dari survei yang dilakukan, antara lain:

1. survei geometri, untuk mengetahui karakteristik jalan seperti lebar lajur dan median;

2. survei volume kendaraan pada tanggal 9 Maret 2020 pukul 06.00-07.00, untuk menghitung jumlah kendaraan yang melewati titik pengamatan;

3. survei waktu perjalanan pada tanggal 17 Februari 2020, untuk mengetahui waktu total perjalanan beserta tiap tundaan;

4. survei arus bebas dilakukan pada tengah malam saat arus kendaraan mendekati 0 , untuk mengetahui waktu perjalanan serta kecepatan saat melalui ruas tanpa tundaan.

Data sekunder yang digunakan pada penelitian ini adalah peta satelit Google Earth yang akan dijadikan pemodelan pada aplikasi Vissim.

\section{TINJAUAN LITERATUR}

\subsection{Rekayasa Lalu lintas}

Rekayasa lalu lintas adalah suatu ilmu penerapan praktis dari pengetahuan ilmiah dan empiris yang berkenaan dengan perencanaan, desain, dan operasi kendaraan dan orang di ruang lalu lintas jalan untuk mencapai pergerakan yang selamat, efisien, nyaman, ekonomis, dan ramah lingkungan (Susilo, 2015).

1. Rekayasa Lalu Lintas pada Ruas

Rekayasa yang dilakukan pada ruas jalan untuk menambah kapasitas atau untuk menjamin agar jalan yang tersedia dipergunakan pada kapasitas yang tertinggi dan dengan tingkat pelayanan tertinggi. Teknik utama dalam rekayasa lalu lintas pada ruas dapat dilakukan dengan beberapa cara, yaitu:

a. Sistem jalan satu arah, salah satu cara yang paling efektif untuk meningkatkan kapasitas jalan. Dengan cara ini kapasitas dapat bertambah sampai dengan 50\%.

b. Pelarangan parkir di pinggir jalan yang mengurangi daya tampung jalan. Larangan parkir disesuaikan dengan kebutuhan, seperti pada jam sibuk.

c. Rambu Lalu Lintas yang merupakan bagian dari perlengkapan jalan, memuat lambang, huruf, angka dan kalimat yang dapat digunakan untuk memberikan peringatan, larangan, perintah dan petunjuk bagi pemakai jalan. Selain rambu lalu lintas, pengendalian juga dapat menggunakan marka jalan (Susilo, 2015). 
2. Rekayasa Lalu Lintas pada Simpang

Persimpangan salah satu proporsi utama dalam hal hambatan perjalanan, oleh karena itu perbaikan pada persimpangan akan mengurangi hambatan dan meningkatkan kapasitas. Rekayasa yang dapat digunakan pada persimpangan, antara lain:

a. Larangan belok kanan, yang dapat menurunkan titik konflik berpotongan sehingga menurunkan tundaan pada simpang. Larangan belok kanan dapat dilakukan dengan cara putaran $\mathrm{U}$.

b. Pembuatan Lampu Lalu Lintas/Alat Isyarat Lampu Lalu Lintas (APILL) pada persimpangan dapat menurunkan jumlah titik konflik, dengan cara menambah jumlah fase. Namun APILL juga dapat meyebabkan penundaan yang tidak perlu dan simpang tidak termanfaatkan sesuai dengan kemampuan pada saat sepi.

c. Bundaran Lalu Lintas, sebagai alternatif lampu pengatur lalu lintas. Bundaran mengendalikan lalu lintas dengan cara membelokkan kendaraan-kendaraan dari suatu lintasan yang lurus, sehingga memperlambat percepatan, membatasi alih gerak kendaraan menjadi berpencar, bergabung, serta bersilangan, sehingga memperkecil kecepatan- kecepatan relatif dari kendaraan.

\subsection{Persimpangan}

Persimpangan adalah titik pada jaringan jalan dimana jalan-jalan bertemu dan lintasan-lintasan kendaraan saling berpotongan. Lalu lintas yang bergerak pada masingmasing kaki persimpangan menggunakan ruang jalan pada persimpangan secara bersamasama dengan lalu lintas lainnya (Susilo, 2015). Persimpangan merupakan bagian yang tidak terpisahkan dari sistem jalan, persimpangan harus dirancang dengan mempertimbangkan efisiensi, keselamatan, kecepatan, biaya operasi, dan kapasitas. Secara umum terdapat tiga jenis persimpangan, yaitu: (1) persimpangan sebidang, (2) pembagian jalur jalan tanpa ramp, dan (3) simpang-susun (interchange) (Khisty, 2015).

1. Jenis Pertemuan Gerakan pada Persimpangan

Terdapat empat jenis dasar alih gerak kendaraan, yaitu berpotongan (crossing); bersilangan (weaving); berpencar (diverging); bergabung (merging). Alih gerak berpotongan lebih berbahaya daripada bersilangan, dan selanjutnya secara berurutan, hal ini disebabkan karena adanya kecepatan-kecepatan yang relatif lebih besar antara satu lintasan kendaraan dengan lintasan lainnya (Susilo (2015). Empat jenis dasar alih gerak kendaraan dapat dilihat pada Gambar 2. 


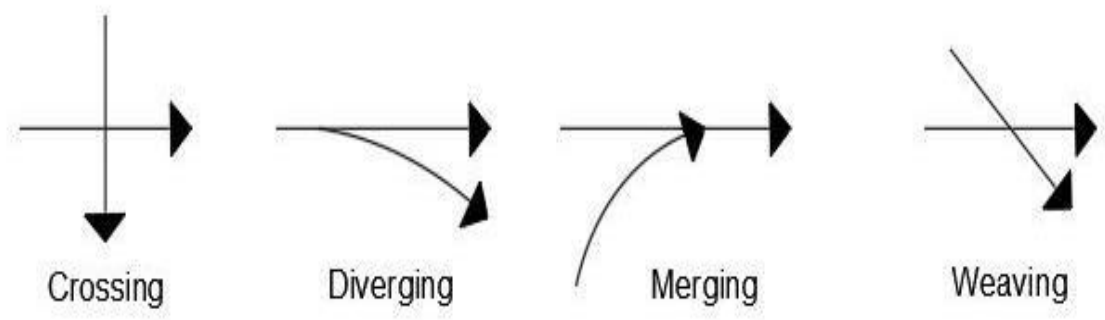

Gambar 2. Empat Jenis Dasar Alih Gerak Persimpangan

2. Daerah Konflik pada Persimpangan

Daerah konflik dapat digambarkan sebagai diagram yang memperlihatkan aliran kendaraan dan alih gerak baik bergabung, menyebar, dan persilangan di simpang dan menentukan jenis konflik dan potensi kecelakaan di simpang. Simpang tiga lengan tanpa sinyal lalu lintas menyebabkan terjadinya tiga titik konflik persilangan, tiga konflik penggabungan, serta tiga titik penyebaran, simpang tiga lengan tanpa sinyal lalu lintas seperti Gambar 3 (a). Simpang tiga lengan dengan sinyal lalu lintas yang menggunakan dua fase, dengan salah satu fase yang dipilih merupakan arah arus konflik utama menyebabkan satu titik konflik persilangan, satu konflik penggabungan, serta dua titik penyebaran, simpang tiga lengan dengan sinyal lalu lintas seperti pada Gambar 3 (b).
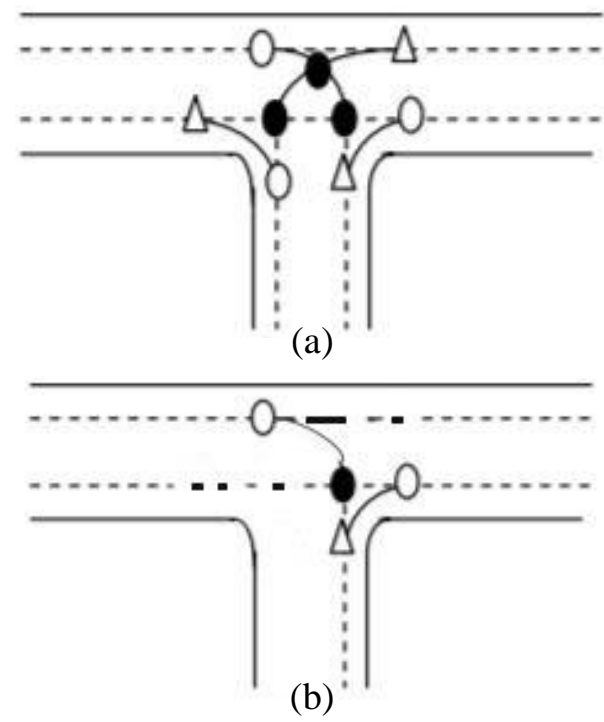

Gambar 3. Simpang Tiga Lengan Tanpa dan Dengan Sinyal Lalu Lintas

\subsection{Tingkat Pelayanan}

Tingkat pelayanan merupakan kemampuan kondisi pengoperasian maksimum suatu jalan serta kualitas jalan tersebut. Tingkat pelayanan adalah kinerja ruas jalan atau 
simpang jalan yang dihitung berdasarkan tingkat penggunaan jalan, kecepatan dan hambatan.

Highway Capacity Manual (HCM) mengeluarkan nilai level of service (LoS) berdasarkan persentase nilai kecepatan perjalanan terhadap kecepatan arus bebas serta nilai derajat kejenuhan dari ruas jalan. Penelitian ini menggunakan nilai level of service berdasarkan HCM dikarenakan aplikasi Vissim merujuk HCM 2010. Terdapat perbedaan penggunaan satuan kecepatan pada HCM dengan MKJI namun dikarenakan pada tingkat pelayanan HCM yang digunakan merupakan bentuk presentase maka apabila kecepatan arus bebas menggunakan perhitungan kecepatan praktis dengan satuan $\mathrm{km} / \mathrm{jam}$ dan kecepatan perjalanan dengan satuan $\mathrm{km} / \mathrm{jam}$, nilai persentase dapat diperoleh dan tingkat pelayanan berdasarkan HCM dapat digunakan. Tingkat pelayanan berdasarkan Highway Capacity Manual tahun 2010 dapat dilihat pada Tabel 1.

Tabel 1. Tingkat Pelayanan Highway Capacity Manual

\begin{tabular}{ccc}
\hline $\begin{array}{c}\text { Travel Speed as a Percentage of Base Free } \\
\text { Flow Speed }(\%)\end{array}$ & $\begin{array}{c}\text { LOS by Critical Volume to Capacity Ratio } \\
\leq \mathbf{1 . 0}\end{array}$ & $>\mathbf{1 . 0}$ \\
\hline \hline$>85$ & $\mathrm{~A}$ & $\mathrm{~F}$ \\
$>67-85$ & $\mathrm{~B}$ & $\mathrm{~F}$ \\
$>50-67$ & $\mathrm{C}$ & $\mathrm{F}$ \\
$>40-50$ & $\mathrm{D}$ & $\mathrm{F}$ \\
$>30-40$ & $\mathrm{E}$ & $\mathrm{F}$ \\
$<30$ & $\mathrm{~F}$ & $\mathrm{~F}$ \\
\hline
\end{tabular}

Sumber: Highway Capacity Manual, 2010

\subsection{Vissim}

Vissim merupakan perangkat lunak simulasi lalu lintas yang digunakan untuk rekayasa lalu lintas, perencanaan transportasi, waktu sinyal, angkutan umum serta perencanan kota yang bersifat mikroskopis dalam aliran lalu lintas multi modal yang diterjemahkan secara visual dan dikembangkan pada tahun 1992 oleh salah satu perusahaan IT di negara Jerman (Siemens, 2012).

1. Parameter

Terdapat 168 parameter yang tertanam dalam perangkat lunak Vissim. Berdasarkan parameter tersebut dipilih beberapa yang sesuai dengan kondisi lalu lintas heterogen yang ada di Indonesia, untuk menghasilkan model yang sesuai dengan kondisi lapangan. Parameter yang dipilih pada permodelan antara lain (Saputra, 2016):

a. Standstill Distance in Front of Obstacle yaitu parameter jarak aman ketika kendaraan akan berhenti akibat kendaraan yang berhenti atau melakukan perlambatan akibat hambatan dengan satuan meter (m). 
b. Minimum Headway yaitu jarak minimum yang tersedia bagi kendaraan yang didepan untuk melakukan perpindahan lajur atau menyiap.

c. Additive Factor Security yaitu nilai tambahan sebagai parameter jarak aman kendaraan yang akan berhenti.

d. Multiplicative Factor Security yaitu faktor pengali jarak aman kendaraan pada saat akan berhenti.

e. Desired Lateral Position yaitu posisi kendaraan pada saat berada di lajur, artinya kendaraan dapat berada disamping kiri maupun samping kanan.

f. Lane Change Rule yaitu mode perilaku pengemudi pada saat melintas, untuk lalu lintas heterogen sangat cocok menggunakan mode Free Lane Change yang memungkinkan kendaraan menyiap dengan bebas.

g. Overtake at Same Line yaitu perilaku pengemudi kendaraan yang ingin menyiap pada lajur yang sama baik dari sisi sebelah kanan maupun sisi kiri.

h. Lateral Minimum Distance yaitu jarak aman pengemudi pada saat berada di samping kendaraan yang lain. Parameter ini dibagi menjadi dua bagian yaitu jarak kendaraan ketika berada di kecepatan $0 \mathrm{~km} / \mathrm{jam}$ dan $50 \mathrm{~km} / \mathrm{jam}$.

i. Safety Distance Reduction yaitu jarak aman antar kendaraan di depan dan di belakang atau jarak gap dan clearing antar kendaraan. Merupakan parameter yang sangat menentukan, tiap kondisi lalu lintas memiliki jarak aman berbeda.

2. Kalibrasi

Vissim merupakan aplikasi buatan Jerman yang memiliki nilai parameter ataupun karakteristik cara mengemudi yang berbeda dengan Indonesia. Agar didapat hasil simulasi yang sesuai dengan kondisi yang ada di Indonesia, diperlukan proses kalibrasi. Proses kalibrasi dapat dilakukan berdasarkan perilaku pengemudi dengan mengacu pada penelitian-penelitian sebelumnya dan dikolaborasikan dengan proses trial and error sehingga nilai dari pemodelan mendekati hasil data observasi.

Menurut kalibrasi yang telah dilakukan pada penelitian sebelumnya oleh Putri (2015), Ulfah (2017) dan Prahara (2018) terdapat perbedaan nilai default pada aplikasi Vissim dengan kondisi lalu lintas Indonesia. Berdasarkan nilai kalibrasi tersebut didapat parameter pada aplikasi Vissim mengalami penurunan nilai. Namun perlu disadari karakteristik pengendara setiap daerah di Indonesia berbeda, oleh karena itu nilai kalibrasi yang sebelumnya dilakukan hanya dapat dijadikan sebagai referensi bukan menjadi patokan utama. Kalibrasi yang telah dilakukan pada penelitian Putri (2015), Ulfah (2017), dan Prahara (2018) terdapat pada Tabel 2. 
Tabel 2. Kalibrasi Penelitian Ulfah, Putri, dan Prahara

\begin{tabular}{|c|c|c|c|c|}
\hline Parameter & Default & Putri & Ulfah & Prahara \\
\hline Desired position at free flow & $\begin{array}{l}\text { Middle } \\
\text { of Lane }\end{array}$ & Any & Any & Any \\
\hline Overtake on same lane on left and on right & Off & On & On & On \\
\hline Distance standing & $1 \mathrm{~m}$ & $0,2 \mathrm{~m}$ & $0,65 \mathrm{~m}$ & $0,35 \mathrm{~m}$ \\
\hline Distance driving & $1 \mathrm{~m}$ & $0,4 \mathrm{~m}$ & $0,2 \mathrm{~m}$ & $0,50 \mathrm{~m}$ \\
\hline Average standstill distance & $2 \mathrm{~m}$ & $0,6 \mathrm{~m}$ & $0,5 \mathrm{~m}$ & $1,0 \mathrm{~m}$ \\
\hline Additive part of safety distance & $2 \mathrm{~m}$ & $0,6 \mathrm{~m}$ & $0,5 \mathrm{~m}$ & $1,0 \mathrm{~m}$ \\
\hline Multiplicative part of safety distance & $3 \mathrm{~m}$ & $1,0 \mathrm{~m}$ & $1,0 \mathrm{~m}$ & $1,5 \mathrm{~m}$ \\
\hline
\end{tabular}

Sumber: Ulfah, Putri dan Prahara, 2019

\section{Validasi}

Validasi pada Vissim merupakan proses pengujian kebenaran dari kalibrasi dengan membandingkan hasil observasi dan hasil simulasi. Proses kalibrasi dan validasi dilakukan berdasarkan jumlah volume arus lalu lintas pada hasil pemodelan dan hasil observasi serta panjang antrean (Putri, 2015).

Statistik GEH merupakan rumus yang umum atau sering digunakan pada rekayasa lalu lintas, peramalan dan pemodelan lalu lintas untuk menghitung volume lalu lintas berdasarkan observasi dan pemodelan. Rumus GEH sendiri dapat dilihat pada persamaan 2.1 dan memiliki ketentuan khusus dari nilai error yang dihasilkan seperti pada Tabel 3 .

$$
\mathrm{GEH}=\sqrt{\frac{\left(\mathrm{q}_{\text {simulated }}-\mathrm{q}_{\text {observed }}\right)^{2}}{0,5\left(\mathrm{q}_{\text {simulated }}+\mathrm{q}_{\text {observed }}\right)}}
$$

Keterangan:

$\mathrm{q}_{\text {simulated }}$ : data volume arus lalu lintas simulasi (kendaraan/jam)

qobserved : data volume arus lalu lintas observasi (kendaraan/jam)

Tabel 3. Kesimpulan Hasil Perhitungan Rumus Statistik Geoffrey E.Havers

\begin{tabular}{cc}
\hline Nilai GEH & Kesimpulan \\
\hline \hline GEH $<5,0$ & Diterima \\
$5,0 \leq \mathrm{GEH} \leq 10,0$ & Peringatan: kemungkinan model error atau data buruk \\
$\mathrm{GEH}>10,0$ & Ditolak \\
\hline
\end{tabular}

\section{ANALISIS DATA}

\subsection{Data Observasi}

Data observasi pada penelitian ini diperoleh sebelum terjadinya pandemi Covid-

19 di Indonesia, data primer yang diperoleh seperti pada penjabaran berikut.

\subsubsection{Data Geometri Jalan}


Data geometri berisi dimensi jalan, lajur, serta arah gerak pada ruas Jalan A.H.

Nasution. Kondisi geometri ruas jalan seperti pada Tabel 4.

Tabel 4. Data Geometri Ruas Jalan A.H. Nasution

\begin{tabular}{ccccccc}
\hline Data & \multicolumn{2}{c}{ Sta $(\mathbf{0 + 0 0 0})-$} & \multicolumn{2}{c}{ Sta $(\mathbf{0 + 2 5 0 )}-$} & \multicolumn{2}{c}{ Sta $(\mathbf{0 + 5 0 0 )}-$} \\
Geometri & \multicolumn{2}{c}{ Sta $(\mathbf{0 + 2 5 0 )}$} & \multicolumn{2}{c}{ Sta $(\mathbf{0 + 5 0 0 )}$} & \multicolumn{2}{c}{ Sta $(\mathbf{3 + 5 5 0 )}$} \\
\hline \hline & Timur & Barat & Timur & Barat & Timur & Barat \\
Jumlah Lajur & 4 & 4 & 4 & 4 & 4 & 4 \\
Jumlah Jalur & 2 & 2 & 2 & 2 & 2 & 2 \\
Lebar Lajur & $2 \times 3,75$ & $2 \times 3,75$ & $2 \times 3$ & $2 \times 2,75$ & $2 \times 2,7$ & $2 \times 2,6$ \\
Lebar Median & 1,5 & 1,5 & 1 & 1 & - & - \\
\hline
\end{tabular}

\subsubsection{Data Volume Lalu Lintas}

Volume lalu lintas adalah jumlah kendaraan yang melewati suatu titik atau ruas jalan tertentu dalam satu waktu pada setiap periode. Total kendaraan pada tiap pendekat tidak perlu dikali dengan koefisien pada aplikasi Vissim, sehingga yang diperlukan hanya jumlah kendaraan sesuai dengan klasifikasi seperti pada Tabel 5.

Tabel 5. Data Volume Lalu Lintas

\begin{tabular}{clcccc}
\hline Simpang & \multicolumn{1}{c}{ Pendekat } & LV & HV & MC & Total (kend/jam) \\
\hline \hline \multirow{2}{*}{ Simpang A.H Nasution } & A.H Nasution (timur) & 596 & 73 & 2354 & 3023 \\
- Antapani Lama & A.H Nasution (barat) & 1049 & 61 & 7159 & 8269 \\
& Antapani Lama & 84 & 0 & 305 & 389 \\
& T. Cicaheum & 57 & 68 & 170 & 295 \\
\hline \multirow{2}{*}{ Simpang A.H Nasution } & A.H Nasution (timur) & 427 & 14 & 1581 & 2631 \\
- Cikadut & A.H Nasution (barat) & 1017 & 61 & 7121 & 8199 \\
& Cikadut & 91 & 0 & 305 & 396 \\
\hline \multirow{2}{*}{ Simpang A.H Nasution } & A.H Nasution (timur) & 440 & 58 & 2143 & 2641 \\
- Pacuan Kuda & A.H Nasution (barat) & 981 & 59 & 6998 & 8038 \\
& Pacuan Kuda & 158 & 2 & 594 & 754 \\
\hline \multirow{2}{*}{ Simpang A.H Nasution } & A.H Nasution (timur) & 92 & 3 & 444 & 539 \\
- Pasir Impun & A.H Nasution (barat) & 451 & 56 & 2306 & 2813 \\
& Pasir Impun & 981 & 59 & 6998 & 8038 \\
\hline \multirow{2}{*}{ Simpang A.H Nasution } & A.H Nasution (timur) & 44 & 3 & 334 & 378 \\
- Arcamanik & A.H Nasution (barat) & 472 & 55 & 2392 & 2919 \\
& Arcamanik & 995 & 59 & 6952 & 8006 \\
\hline \multirow{2}{*}{ Simpang A.H Nasution } & A.H Nasution (timur) & 84 & 0 & 439 & 523 \\
- Cicukang & A.H Nasution (barat) & 462 & 55 & 2375 & 2892 \\
& Cicukang & 982 & 59 & 6929 & 7970 \\
\hline
\end{tabular}




\subsubsection{Data Waktu Perjalanan}

Data waktu perjalanan ruas Jalan A.H. Nasution pada Tabel 6 diperoleh sebelum terjadinya wabah Covid-19, data ini berisikan waktu perjalanan total, tundaan serta kecepatan perjalanan serta kecepatan bergerak yang diperoleh dari survei waktu perjalanan pada kedua arah. Waktu perjalanan terlama ditempuh selama 1468 detik (24,5 menit) pada hari Senin, 17 Februari 2020 pukul 06.40 menuju A.H. Nasution (timur) atau Simpang Ahmad Yani - Cicaheum.

Tabel 6. Data Waktu Perjalanan

\begin{tabular}{|c|c|c|c|c|c|c|c|}
\hline Kota: & Bandun & & & Tanggal: & \multicolumn{3}{|c|}{17 Pebr 2020} \\
\hline $\begin{array}{l}\text { Panjang: } \\
\text { Arah: }\end{array}$ & $\begin{array}{l}\mathrm{g} \\
3,55 \mathrm{~km} \\
\text { Barat }\end{array}$ & & & $\begin{array}{l}\text { Simpul: } \\
\text { Waktu: }\end{array}$ & \multicolumn{3}{|c|}{$\begin{array}{l}\text { Ditbintekjatan ke Cicaheum } \\
06: 40: 00\end{array}$} \\
\hline \multicolumn{4}{|c|}{ Titik Kontrol } & \multicolumn{2}{|c|}{ Berhenti } & Kecepata & Kecepata \\
\hline Dari & $\mathrm{Ke}$ & $\begin{array}{c}\text { Waktu } \\
\text { Perjalana } \\
\text { n }\end{array}$ & $\begin{array}{l}\text { Panjan } \\
\mathrm{g}(\mathrm{m})\end{array}$ & $\begin{array}{c}\text { Hambata } \\
\mathrm{n} \text { (detik) }\end{array}$ & $\begin{array}{c}\text { Waktu } \\
\text { Bergera } \\
\text { k }\end{array}$ & $\begin{array}{c}\mathrm{n} \\
\text { Perjalana } \\
\mathrm{n} \\
(\mathrm{km} / \mathrm{jam})\end{array}$ & $\begin{array}{c}\mathrm{n} \\
\text { Bergerak } \\
(\mathrm{km} / \mathrm{jam})\end{array}$ \\
\hline $\begin{array}{l}\text { Ditbintekjata } \\
\mathrm{n}\end{array}$ & P.Impun & $00: 05: 47$ & 950 & $00: 04: 37$ & $00: 01: 10$ & & 48,86 \\
\hline Pasir Impun & Cikadut & 00:09:17 & 1400 & 00:06:22 & $00: 02: 55$ & & 28,80 \\
\hline Cikadut & $\begin{array}{l}\text { Cicaheu } \\
\text { m }\end{array}$ & 00:09:24 & 1200 & 00:08:28 & 00:00:56 & 8,71 & 77,14 \\
\hline Total & & $\begin{array}{c}00: 24: 28 \\
1468\end{array}$ & 3550 & $\begin{array}{c}00: 19: 27 \\
1167\end{array}$ & $\begin{array}{c}00: 05: 01 \\
301\end{array}$ & & \\
\hline
\end{tabular}

\subsubsection{Data Kecepatan Arus Bebas}

Pengambilan data kecepatan arus bebas dilakukan pada tanggal 19 Februari 2020 pukul 01.00 WIB. Berdasarkan hasil perhitungan stopwatch diperoleh waktu perjalanan pada tingkat arus mendekati nol selama 370 detik.

\subsection{Kalibrasi dan Validasi Vissim}

Kalibrasi dilakukan dengan mengubah parameter-parameter perilaku pengemudi secara trial and error dengan mengacu pada nilai parameter penelitian sebelumnya, selanjutnya dilakukan analisa dengan uji GEH (Geoffrey E. Havers). Hasil validasi dengan rumus GEH terhadap volume harus dilakukan sesuai dengan syarat yang berlaku. Nilai kalibrasi dan hasil validasi dapat dilihat pada Tabel 7 dan Tabel 8.

Validasi juga dilakukan terhadap waktu perjalanan antara kondisi lapangan dengan hasil pemodelan pada aplikasi Vissim. Hasil validasi waktu perjalanan dapat dilihat pada Tabel 9. 
Tabel 7. Nilai Parameter Kalibrasi pada Tiap Simpang

\begin{tabular}{|c|c|c|c|c|c|c|c|c|}
\hline \multirow[b]{2}{*}{ Simpang } & \multirow[b]{2}{*}{ Arah } & \multicolumn{7}{|c|}{ Parameters } \\
\hline & & $\begin{array}{c}\text { Average } \\
\text { Standstill } \\
\text { Distance }\end{array}$ & $\begin{array}{c}\text { Additive } \\
\text { Part of } \\
\text { Safety }\end{array}$ & $\begin{array}{c}\text { Multi } \\
\text { Part } \\
\text { of } \\
\text { Safety }\end{array}$ & $\begin{array}{l}\text { Desired } \\
\text { Position }\end{array}$ & $\begin{array}{c}\text { Overtake } \\
\text { Left \& } \\
\text { Right }\end{array}$ & $\begin{array}{l}\text { Distance } \\
\text { Standing }\end{array}$ & $\begin{array}{c}\text { Distance } \\
\text { Driving }\end{array}$ \\
\hline \multirow{2}{*}{$\begin{array}{l}\text { A.H } \\
\text { Nasution- } \\
\text { Antapani } \\
\text { Lama }\end{array}$} & Timur & 0,60 & 1 & 1,50 & Any & On & 0,35 & 0,5 \\
\hline & Barat & 0,35 & 1 & 1 & Any & On & 0,35 & 0,5 \\
\hline \multirow{2}{*}{$\begin{array}{l}\text { A.H } \\
\text { Nasution- } \\
\text { Cikadut }\end{array}$} & Timur & 0,40 & 1 & 1,50 & Any & On & 0,35 & 0,5 \\
\hline & Barat & 0,20 & 0,60 & 1 & Any & On & 0,2 & 0,5 \\
\hline \multirow{2}{*}{$\begin{array}{l}\text { A.H } \\
\text { Nasution- } \\
\text { Pacuan } \\
\text { Kuda }\end{array}$} & Timur & 0,40 & 0,50 & 1,50 & Any & $O n$ & 0,25 & 0,5 \\
\hline & Barat & 0,20 & 0,50 & 1 & Any & On & 0,2 & 0,7 \\
\hline \multirow{2}{*}{$\begin{array}{l}\text { A.H } \\
\text { Nasution- } \\
\text { P. Impun }\end{array}$} & Timur & 0,50 & 0,50 & 1 & Any & On & 0,25 & 1 \\
\hline & Barat & 0,25 & 0,50 & 1 & Any & On & 0,2 & 0,7 \\
\hline \multirow{2}{*}{$\begin{array}{l}\text { A.H } \\
\text { Nasution- } \\
\text { Arcamanik }\end{array}$} & Timur & 0,50 & 0,50 & 1 & Any & On & 0,25 & 1 \\
\hline & Barat & 0,25 & 0,50 & 1 & Any & On & 0,2 & 0,7 \\
\hline \multirow{2}{*}{$\begin{array}{l}\text { A.H } \\
\text { Nasution- } \\
\text { Cicukang }\end{array}$} & Timur & 0,50 & 0,50 & 1 & Any & On & 0,25 & 1 \\
\hline & Barat & 0,25 & 0,50 & 1 & Any & On & 0,2 & 0,7 \\
\hline
\end{tabular}

Tabel 8. Validasi Volume dengan Uji Geoffrey E. Havers

\begin{tabular}{|c|c|c|c|c|c|}
\hline Simpang & Pendekat & Observasi & Model & GEH & Kesimpulan \\
\hline \multirow{4}{*}{$\begin{array}{l}\text { A.H Nasution- } \\
\text { Antapani Lama }\end{array}$} & A.H Nasution (Barat) & 3023 & 3105 & 1,48 & Diterima \\
\hline & A.H Nasution (Timur) & 8269 & 7922 & 3,86 & Diterima \\
\hline & Antapani Lama & 295 & 270 & 1,49 & Diterima \\
\hline & Terminal Cicaheum & 389 & 390 & 0,05 & Diterima \\
\hline \multirow{3}{*}{$\begin{array}{l}\text { A.H Nasution- } \\
\text { Cikadut }\end{array}$} & A.H Nasution (Barat) & 2631 & 2770 & 2,67 & Diterima \\
\hline & A.H Nasution (Timur) & 8199 & 7941 & 2,87 & Diterima \\
\hline & Cikadut & 396 & 390 & 0,30 & Diterima \\
\hline \multirow{3}{*}{$\begin{array}{l}\text { A.H Nasution- } \\
\text { Pacuan Kuda }\end{array}$} & A.H Nasution (Barat) & 2641 & 2723 & 1,58 & Diterima \\
\hline & A.H Nasution (Timur) & 8038 & 7709 & 3,71 & Diterima \\
\hline & Pacuan Kuda & 754 & 751 & 0,11 & Diterima \\
\hline \multirow{4}{*}{$\begin{array}{l}\text { A.H Nasution- } \\
\text { P.Impun \& } \\
\text { Arcamanik }\end{array}$} & A.H Nasution (Barat) & 2813 & 2916 & 1,92 & Diterima \\
\hline & A.H Nasution (Timur) & 8006 & 7628 & 3,66 & Diterima \\
\hline & Pasir Impun & 539 & 545 & 0,26 & Diterima \\
\hline & Arcamanik & 378 & 354 & 1,25 & Diterima \\
\hline \multirow{3}{*}{$\begin{array}{l}\text { A.H Nasution- } \\
\text { Cicukang }\end{array}$} & A.H Nasution (Barat) & 2892 & 3024 & 2,43 & Diterima \\
\hline & A.H Nasution (Timur) & 7970 & 7605 & 4,14 & Diterima \\
\hline & Cicukang & 523 & 522 & 0,04 & Diterima \\
\hline
\end{tabular}

Tabel 9. Validasi Waktu Perjalanan

\begin{tabular}{llccc}
\hline \multicolumn{1}{c}{ Dari } & \multicolumn{1}{c}{ Menuju } & \multicolumn{2}{c}{ Waktu Perjalanan (detik) } & \multirow{2}{*}{$\begin{array}{c}\text { Selisih } \\
\text { (\%) }\end{array}$} \\
\cline { 3 - 4 } & & Observasi & Model & 0,96 \\
Ditbintekjatan Sta (3+550) & Pasir Impun Sta (2+600) & 347 & 350,34 & 0,34 \\
Pasir Impun Sta (2+600) & Cikadut Sta (1+200) & 557 & 536,46 & 3,69 \\
Cikadut Sta (1+200) & Cicaheum Sta (0+000) & 564 & 540,44 & 4,18 \\
Total & & 1468 & 1427,24 & 2,78 \\
\hline
\end{tabular}




\subsection{Hasil Penelitian Kondisi Eksisting}

Simulasi Vissim yang dilakukan sesuai dengan data yang ada dan dikalibrasi menggunakan parameter-parameter yang telah disebutkan pada Tabel 7 dan Tabel 8. Hasil penelitian dari simulasi Vissim berupa Level of Service (LoS) beserta tundaan pada setiap simpang dan waktu perjalanan.

\subsubsection{Tingkat Pelayanan Simpang Kondisi Eksisting}

Simulasi penelitian ini dibagi berdasarkan segmen, dikarenakan aplikasi Vissim yang digunakan hanya mampu melakukan pemodelan maksimal $1 \mathrm{~km}$ sehingga harus dilakukan pembagian pemodelan sesuai dengan batas maksimum Panjang yang disediakan oleh Vissim. Hasil simulasi pada aplikasi Vissim untuk simpang tanpa perubahan (eksisting) dapat dilihat pada Tabel 10.

Tabel 10. Tingkat Pelayanan Simpang Kondisi Eksisting

\begin{tabular}{lcc}
\hline \multicolumn{1}{c}{ Simpang } & Panjang antrean maks(m) & LoS \\
\hline \hline A.H Nasution - Antapani & 413 & F \\
A.H Nasution - Cikadut & 461 & E \\
A.H Nasution - Pacuan Kuda & 282 & D \\
A.H Nasution - Pasir Impun & 291 & D \\
A.H Nasution - Arcamanik & 217 & E \\
A.H Nasution - Cicukang & 346 & D \\
\hline
\end{tabular}

\subsubsection{Tundaan Kondisi Eksisting}

Tundaan yang terjadi pada setiap segmen pada ruas Jalan A.H Nasution disebabkan oleh banyaknya kendaraan yang keluar atau menuju ke jalan minor pada simpang tidak bersinyal atau dapat disebut juga sebagai tundaan operasional. Tundaan eksisting pada ruas Jalan A.H Nasution dapat dilihat pada Tabel 11.

Tabel 11. Tundaan Kondisi Eksisting

\begin{tabular}{lccc}
\hline \multicolumn{1}{c}{ Stationing } & Menuju & Jarak $(\mathbf{m})$ & Tundaan (detik) \\
\hline \hline Sta $(0+000)-$ & Barat & 700 & 75,80 \\
Sta $(0+700)$ & Timur & & 82,10 \\
\hline Sta $(0+700)-$ & Barat & \multirow{2}{*}{950} & 77,18 \\
Sta $(1+650)$ & Timur & & 113,22 \\
\hline Sta $(1+650)-$ & Barat & \multirow{2}{*}{700} & 82,76 \\
Sta $(2+350)$ & Timur & & 40,99 \\
\hline Sta $(2+350)-$ & Barat & 700 & 76,14 \\
Sta $(3+050)$ & Timur & & 150,97 \\
\hline
\end{tabular}


Tabel 11. Tundaan Kondisi Eksisting (Lanjutan)

\begin{tabular}{|c|c|c|c|}
\hline Stationing & Menuju & Jarak (m) & Tundaan (detik) \\
\hline \multirow{2}{*}{$\begin{array}{l}\text { Sta }(3+050)- \\
\text { Sta }(3+550)\end{array}$} & Barat & \multirow{2}{*}{500} & 33,65 \\
\hline & Timur & & 23,15 \\
\hline \multirow{2}{*}{ Total } & Barat & \multirow{2}{*}{3550} & 345,53 \\
\hline & Timur & & 410,43 \\
\hline
\end{tabular}

\subsubsection{Waktu Perjalanan Kondisi Eksisting}

Waktu perjalanan eksisting didapat dari pemodelan yang telah dilakukan pada masing-masing segmen dan dijumlahkan untuk mendapat waktu keseluruhan pada ruas Jalan A.H. Nasution. Waktu perjalanan eksisting dapat dilihat pada Tabel 12.

Tabel 12. Waktu Perjalanan Eksisting

\begin{tabular}{|c|c|c|c|}
\hline Stationing & Menuju & Jarak (m) & Wkt Perjalanan (detik) \\
\hline \multirow{2}{*}{$\begin{array}{l}\text { Sta }(0+000)- \\
\text { Sta }(0+700)\end{array}$} & Barat & \multirow{2}{*}{700} & 385,61 \\
\hline & Timur & & 355,61 \\
\hline \multirow{2}{*}{$\begin{array}{l}\text { Sta }(0+700)- \\
\text { Sta }(1+650)\end{array}$} & Barat & \multirow{2}{*}{950} & 294,18 \\
\hline & Timur & & 341,55 \\
\hline \multirow{2}{*}{$\begin{array}{l}\text { Sta }(1+650)- \\
\text { Sta }(2+350)\end{array}$} & Barat & \multirow{2}{*}{700} & 280,22 \\
\hline & Timur & & 184,42 \\
\hline \multirow{2}{*}{$\begin{array}{l}\text { Sta }(2+350)- \\
\text { Sta }(3+050)\end{array}$} & Barat & \multirow{2}{*}{700} & 327,29 \\
\hline & Timur & & 328,32 \\
\hline \multirow{2}{*}{$\begin{array}{l}\text { Sta }(3+050)- \\
\text { Sta }(3+550)\end{array}$} & Barat & \multirow{2}{*}{500} & 139,95 \\
\hline & Timur & & 119,95 \\
\hline \multirow{2}{*}{ Total } & Barat & \multirow{2}{*}{3550} & 1427,25 \\
\hline & Timur & & 1329,86 \\
\hline
\end{tabular}

\subsubsection{Tingkat Pelayanan Ruas Kondisi Eksisting}

Dari hasil penelitian eksisting selain diperoleh nilai Level of Service setiap simpang seperti pada Tabel 13, diperoleh juga nilai waktu perjalanan pada setiap segmen sehingga dapat diperoleh kecepatan serta nilai Level of Service baik pada segmen maupun ruas secara keseluruhan.

Tabel 13. Tingkat Pelayanan Ruas Kondisi Eksisting

\begin{tabular}{lccc}
\hline \multicolumn{1}{c}{ Stationing } & Menuju & Panjang $(\mathbf{m})$ & LoS \\
\hline \hline Sta $(0+000)-$ & Timur & \multirow{2}{*}{700} & $\mathrm{~F}$ \\
Sta $(0+700)$ & Barat & & F \\
\hline Sta $(0+700)-$ & Timur & \multirow{2}{*}{950} & F \\
Sta $(1+650)$ & Barat & & E \\
\hline
\end{tabular}


Tabel 13. Tingkat Pelayanan Ruas Kondisi Eksisting (Lanjutan)

\begin{tabular}{lccc}
\hline \multicolumn{1}{c}{ Stationing } & Menuju & Panjang $(\mathbf{m})$ & LoS \\
\hline \hline Sta $(1+650)-$ & Timur & \multirow{2}{*}{700} & E \\
Sta $(2+350)$ & Barat & \multirow{2}{*}{700} & F \\
\hline Sta $(2+350)-$ & Timur & \multirow{2}{*}{ F } \\
Sta $(3+050)$ & Barat & \multirow{2}{*}{500} & F \\
\hline Sta $(3+050)-$ & Timur & D \\
Sta $(3+550)$ & Barat & \multirow{2}{*}{3550} & F \\
\hline Sta $(0+000)-$ & Timur & \multirow{2}{*}{$350)$} \\
Sta $(3+550)$ & Barat & & F \\
\hline
\end{tabular}

\subsection{Hasil Penelitian Kondisi Solusi Alternatif}

Solusi alternatif yang dilakukan pada penelitian ini adalah pelebaran jalan serta larangan belok kanan dan menggunakan $u$-turn dengan floating median. Pelebaran jalan dapat dilakukan dengan cara memperkecil median ataupun dengan menggunakan rumija. Pada penelitian ini terdapat lima segmen, pada segmen pertama dilakukan pelebaran jalan dan untuk segmen kedua hingga kelima diberlakukan larangan belok kanan. Pelebaran lajur dapat dilihat pada Tabel 14 .

Tabel 14. Perubahan Lebar Lajur Sta $(0+000)-(0+500)$

\begin{tabular}{lccccccccc}
\hline \multirow{2}{*}{ Stationing } & \multicolumn{3}{c}{ Sebelum (m) } & \multicolumn{3}{c}{ Sesudah (m) } \\
\cline { 2 - 9 } & \multicolumn{2}{c}{ Timur } & \multicolumn{2}{c}{ Barat } & \multicolumn{2}{c}{ Timur } & \multicolumn{3}{c}{ Barat } \\
\cline { 2 - 9 } & $\mathbf{1}$ & $\mathbf{2}$ & $\mathbf{1}$ & $\mathbf{2}$ & $\mathbf{1}$ & $\mathbf{2}$ & $\mathbf{1}$ & $\mathbf{2}$ \\
\hline \hline Sta $(0+000)-$ Sta $(0+250)$ & 3,75 & 3,75 & 3,75 & 3,75 & 4,25 & 4 & 4,25 & 4 \\
Sta $(0+250)-$ Sta $(0+500)$ & 3 & 3 & 2,75 & 2,75 & 3,75 & 3,75 & 3,75 & 3,75 \\
\hline
\end{tabular}

\subsubsection{Tingkat Pelayanan Simpang Kondisi Alternatif}

Solusi alternatif diperlukan untuk meningkatkan kinerja ruas maupun kinerja simpang. Peningkatan kinerja ruas ataupun simpang dapat dilihat dari nilai LoS, waktu perjalanan, dan tundaan.. Tingkat pelayanan simpang kondisi alternatif dapat dilihat pada Tabel 15.

Tabel 15. Tingkat Pelayanan Simpang Kondisi Alternatif

\begin{tabular}{cccc}
\hline Segmen & Simpang & Panjang antrean maks(m) & LoS \\
\hline \hline 1 & A.H Nasution - Antapani & 154 & $\mathrm{C}$ \\
\hline \multirow{2}{*}{2} & U Turn (barat) & 53 & $\mathrm{~A}$ \\
& A.H Nasution - Cikadut & 26 & $\mathrm{~A}$ \\
& $U$ Turn (timur) & 126 & $\mathrm{C}$ \\
\hline
\end{tabular}


Tabel 15. Tingkat Pelayanan Simpang Kondisi Alternatif (Lanjutan)

\begin{tabular}{cccc}
\hline Segmen & Simpang & Panjang antrean maks(m) & LoS \\
\hline \hline \multirow{3}{*}{3} & U Turn (barat) & 140 & $\mathrm{~A}$ \\
& A.H Nasution - Pacuan Kuda & 135 & $\mathrm{~B}$ \\
& U Turn (timur) & 220 & $\mathrm{C}$ \\
\hline \multirow{4}{*}{4} & U Turn (barat) & 118 & $\mathrm{C}$ \\
& A.H Nasution - Pasir Impun & 29 & $\mathrm{~A}$ \\
& A.H Nasution - Arcamanik & 40 & $\mathrm{~A}$ \\
& U Turn (timur) & 84 & $\mathrm{~B}$ \\
\hline \multirow{3}{*}{5} & U Turn (barat) & 109 & $\mathrm{~A}$ \\
& A.H Nasution - Cicukang & 105 & $\mathrm{~B}$ \\
& U Turn (timur) & 218 & $\mathrm{~B}$ \\
\hline
\end{tabular}

\subsubsection{Tundaan Simpang Kondisi Alternatif}

Kondisi alternatif yang telah dilakukan menyebabkan turunnya tundaan pada setiap simpang sehingga menyebabkan naiknya tingkat pelayanan pada setiap simpang. Tundaan yang terjadi saat pemodelan kondisi alternatif dapat dilihat pada Tabel 16.

Tabel 16. Tundaan Simpang Kondisi Alternatif

\begin{tabular}{|c|c|c|c|}
\hline Stationing & Menuju & Jarak (m) & Tundaan (detik) \\
\hline \multirow{2}{*}{$\begin{array}{l}\text { Sta }(0+000)- \\
\text { Sta }(0+700)\end{array}$} & Barat & \multirow{2}{*}{700} & 30,91 \\
\hline & Timur & & 5,49 \\
\hline \multirow{2}{*}{$\begin{array}{l}\text { Sta }(0+700)- \\
\text { Sta }(1+650)\end{array}$} & Barat & \multirow{2}{*}{950} & 33,50 \\
\hline & Timur & & 49,22 \\
\hline \multirow{2}{*}{$\begin{array}{l}\text { Sta }(1+650)- \\
\text { Sta }(2+350)\end{array}$} & Barat & \multirow{2}{*}{700} & 63,55 \\
\hline & Timur & & 40,22 \\
\hline \multirow{2}{*}{$\begin{array}{l}\text { Sta }(2+350)- \\
\text { Sta }(3+050)\end{array}$} & Barat & \multirow{2}{*}{700} & 62,68 \\
\hline & Timur & & 24,03 \\
\hline \multirow{2}{*}{$\begin{array}{l}\text { Sta }(3+050)- \\
\text { Sta }(3+550)\end{array}$} & Barat & \multirow{2}{*}{500} & 35,41 \\
\hline & Timur & & 13,17 \\
\hline \multirow{2}{*}{ Total } & Barat & \multirow{2}{*}{3550} & 226,05 \\
\hline & Timur & & 132,13 \\
\hline
\end{tabular}

\subsubsection{Waktu Perjalanan Simpang Kondisi Alternatif}

Penerapan kondisi alternatif yang telah dilakukan berpengaruh juga terhadap peningkatan waktu perjalanan dikarenakan turunnya tingkat tundaan pada setiap simpang. Hasil penelitan mengenai waktu perjalanan alternatif dapat dilihat pada Tabel 17. 
Tabel 17. Waktu Perjalanan Kondisi Alternatif

\begin{tabular}{lccc}
\hline \multicolumn{1}{c}{ Stationing } & Menuju & Jarak $(\mathbf{m})$ & Wkt Perjalanan (detik) \\
\hline \hline Sta $(0+000)-$ & Barat & \multirow{2}{*}{700} & $\begin{array}{c}160,26 \\
94,64\end{array}$ \\
Sta $(0+700)$ & Timur & & 182,87 \\
Sta $(0+700)-$ & Barat & \multirow{2}{*}{950} & 213,59 \\
Sta $(1+650)$ & Timur & & 227,24 \\
\hline Sta $(1+650)-$ & Barat & \multirow{2}{*}{700} & 174,76 \\
Sta $(2+350)$ & Timur & & 226,63 \\
Sta $(2+350)-$ & Barat & \multirow{2}{*}{700} & 177,58 \\
Sta $(3+050)$ & Timur & & 120,21 \\
\hline Sta $(3+050)-$ & Barat & \multirow{2}{*}{500} & 72,97 \\
Sta $(3+550)$ & Timur & & 913,51 \\
\multicolumn{5}{c}{ Total } & Barat & \multirow{2}{*}{3550} & 733,54 \\
\hline
\end{tabular}

\subsubsection{Tingkat Pelayanan Ruas Kondisi Alternatif}

Berdasarkan hasil perbaikan dengan solusi alternatif pada setiap simpang diperoleh nilai $L o S$ setiap simpang. Selain itu diperoleh juga nilai waktu perjalanan serta tundaan pada simpang tersebut. Nilai $L o S$ ruas jalan A.H Nasution setelah dilakukan perbaikan dapat dilihat pada Tabel 18 .

Tabel 18. Tingkat Pelayanan Ruas Kondisi Alternatif

\begin{tabular}{lccc}
\hline \multicolumn{1}{c}{ Stationing } & Menuju & Panjang $(\mathbf{m})$ & LoS \\
\hline \hline Sta $(0+000)-$ & Timur & \multirow{2}{*}{700} & B \\
Sta $(0+700)$ & Barat & & D \\
\hline Sta $(0+700)-$ & Timur & \multirow{2}{*}{950} & D \\
Sta $(1+650)$ & Barat & & C \\
\hline Sta $(1+650)-$ & Timur & 700 & D \\
Sta $(2+350)$ & Barat & & E \\
\hline Sta $(2+350)-$ & Timur & 700 & D \\
Sta $(3+050)$ & Barat & & E \\
\hline Sta $(3+050)-$ & Timur & 500 & B \\
Sta $(3+550)$ & Barat & & D \\
\hline Sta $(0+000)-$ & Timur & 3550 & C \\
Sta $(3+550)$ & Barat & & D \\
\hline
\end{tabular}

\subsection{Perbandingan Kondisi Eksisting dan Alternatif}

Setelah dilakukan pemodelan solusi alternatif pada ruas jalan yang ditinjau terdapat penurunan nilai tundaan arah timur menuju barat dari 345 detik menjadi 226 detik dan arah barat menuju timur dari 410 detik menjadi 132 detik. Waktu perjalanan dari arah timur menuju barat dari 1427 detik menjadi 913 detik dan arah barat menuju timur dari 1329 detik menjadi 733 detik. Perbandingan hasil kondisi eksisting dan alternatif dengan beberapa parameter dapat dilihat pada Tabel $19 \mathrm{~s} / \mathrm{d}$ Tabel 21. 
Tabel 19. Perbandingan Tundaan Kondisi Eksisting dan Alternatif

\begin{tabular}{|c|c|c|c|c|}
\hline \multirow{2}{*}{ Stationing } & \multirow{2}{*}{ Menuju } & \multirow{2}{*}{ Jarak (m) } & \multicolumn{2}{|c|}{ Tundaan (detik) } \\
\hline & & & Eksisting & Alternatif \\
\hline \multirow{2}{*}{$\begin{array}{l}\text { Sta }(0+000)- \\
\text { Sta }(0+700)\end{array}$} & Barat & \multirow{2}{*}{700} & 75,80 & 30,91 \\
\hline & Timur & & 82,10 & 5,49 \\
\hline \multirow{2}{*}{$\begin{array}{l}\text { Sta }(0+700)- \\
\text { Sta }(1+650)\end{array}$} & Barat & \multirow{2}{*}{950} & 77,18 & 33,50 \\
\hline & Timur & & 113,22 & 49,22 \\
\hline \multirow{2}{*}{$\begin{array}{l}\text { Sta }(1+650)- \\
\text { Sta }(2+350)\end{array}$} & Barat & \multirow{2}{*}{700} & 82,76 & 63,55 \\
\hline & Timur & & 40,99 & 40,22 \\
\hline \multirow{2}{*}{$\begin{array}{l}\text { Sta }(2+350)- \\
\text { Sta }(3+050)\end{array}$} & Barat & \multirow{2}{*}{700} & 76,14 & 62,68 \\
\hline & Timur & & 150,97 & 24,03 \\
\hline \multirow{2}{*}{$\begin{array}{l}\text { Sta }(3+050)- \\
\text { Sta }(3+550)\end{array}$} & Barat & \multirow{2}{*}{500} & 33,65 & 35,41 \\
\hline & Timur & & 23,15 & 13,17 \\
\hline \multirow{2}{*}{ Total } & Barat & \multirow{2}{*}{3550} & 345,53 & 226,05 \\
\hline & Timur & & 410,43 & 132,13 \\
\hline
\end{tabular}

Tabel 20. Perbandingan Waktu Perjalanan Kondisi Alternatif dan Alternatif

\begin{tabular}{|c|c|c|c|c|}
\hline \multirow{2}{*}{ Stationing } & \multirow{2}{*}{ Menuju } & \multirow{2}{*}{ Jarak (m) } & \multicolumn{2}{|c|}{ Wkt Perjalanan (detik) } \\
\hline & & & Eksisting & Alternatif \\
\hline \multirow{2}{*}{$\begin{array}{l}\text { Sta }(0+000)- \\
\text { Sta }(0+700)\end{array}$} & Barat & \multirow{2}{*}{700} & 385,61 & 160,26 \\
\hline & Timur & & 355,61 & 94,64 \\
\hline \multirow{2}{*}{$\begin{array}{l}\text { Sta }(0+700)- \\
\text { Sta }(1+650)\end{array}$} & Barat & \multirow{2}{*}{950} & 294,18 & 182,87 \\
\hline & Timur & & 341,55 & 213,59 \\
\hline \multirow{2}{*}{$\begin{array}{l}\text { Sta }(1+650)- \\
\text { Sta }(2+350)\end{array}$} & Barat & \multirow{2}{*}{700} & 280,22 & 227,24 \\
\hline & Timur & & 184,42 & 174,76 \\
\hline \multirow{2}{*}{$\begin{array}{l}\text { Sta }(2+350)- \\
\text { Sta }(3+050)\end{array}$} & Barat & \multirow{2}{*}{700} & 327,29 & 226,63 \\
\hline & Timur & & 328,32 & 177,58 \\
\hline \multirow{2}{*}{$\begin{array}{l}\text { Sta }(3+050)- \\
\text { Sta }(3+550)\end{array}$} & Barat & \multirow{2}{*}{500} & 139,95 & 120,21 \\
\hline & Timur & & 119,95 & 72,97 \\
\hline \multirow{2}{*}{ Total } & Barat & \multirow{2}{*}{3550} & 1427,25 & 913,51 \\
\hline & Timur & & 1329,86 & 733,54 \\
\hline
\end{tabular}

Tabel 21. Perbandingan LoS Kondisi Eksisting dan Alternatif

\begin{tabular}{lcccc}
\hline \multirow{2}{*}{ Stationing } & \multirow{2}{*}{ Menuju } & \multirow{2}{*}{ Panjang (m) } & \multicolumn{2}{c}{ Level of Service Ruas } \\
& & & Eksisting & Alternatif \\
\hline \hline Sta $(0+000)-$ & Timur & \multirow{2}{*}{700} & F & B \\
Sta $(0+700)$ & Barat & & F & D \\
\hline Sta $(0+700)-$ & Timur & \multirow{2}{*}{950} & F & D \\
Sta $(1+650)$ & Barat & & E & C \\
\hline Sta $(1+650)-$ & Timur & \multirow{2}{*}{700} & E & D \\
Sta $(2+350)$ & Barat & & F & E \\
\hline Sta $(2+350)-$ & Timur & \multirow{2}{*}{700} & F & D \\
Sta $(3+050)$ & Barat & & F & E \\
\hline Sta $(3+050)-$ & Timur & \multirow{2}{*}{500} & D & B \\
Sta $(3+550)$ & Barat & & E & D \\
\hline Sta $(0+000)-$ & Timur & \multirow{2}{*}{3550} & F & C \\
Sta $(3+550)$ & Barat & & F & D \\
\hline
\end{tabular}




\section{SIMPULAN DAN SARAN}

\subsection{Simpulan}

Berdasarkan analisis ruas Jalan A.H. Nasution yang telah dilakukan dengan aplikasi Vissim diperoleh beberapa kesimpulan sebagai berikut:

1. Hasil kinerja lalu lintas kondisi eksisting ruas Jalan A.H Nasution dari Barat menuju Timur memiliki tingkat pelayanan benilai $\mathrm{F}$ dan dari Timur menuju Barat memiliki tingkat pelayanan bernilai F. Waktu perjalanan dari Barat menuju Timur selama 22 menit 10 detik dengan total tundaan selama 410 detik dan dari Timur menuju Barat selama 23 menit 47 detik dengan total tundaan selama 345 detik.

2. Peningkatan kinerja ruas jalan dilakukan dengan dua alternatif yaitu: pelebaran ruas jalan pada Sta $(0+000)$ - Sta $(0+500)$; larangan belok kanan pada setiap simpang tidak bersinyal yang berada pada ruas Jalan A.H Nasution yaitu: Simpang A.H Nasution-Cikadut, Simpang A.H Nasution-Pacuan Kuda, Simpang A.H NasutionPasir Impun, Simpang A.H Nasution- Arcamanik, dan Simpang A.H NasutionCicukang.

3. Hasil kinerja setelah dilakukan rekayasa lalu lintas menyebabkan perbaikan tingkat pelayanan arus lalu lintas dari Barat menuju Timur yang awalnya bernilai $\mathrm{F}$ menjadi $\mathrm{C}$ dan arus lalu lintas dari Timur menuju Barat dari bernilai F menjadi D. Demikian juga dengan waktu perjalanan dari Barat menuju Timur yang sebelumnya berdurasi 22 menit 10 detik menjadi 12 menit 14 detik dengan tundaan selama 410 detik menjadi 132 detik dan waktu perjalanan dari Timur menuju Barat yang sebelumnya berdurasi 23 menit 47 detik menjadi 15 menit 13 detik dengan tundaan selama 345 detik menjadi 226 detik.

\subsection{Saran}

Adapun saran yang dapat diberikan dari hasil penelitian ini adalah:

1. Perlu dilakukannya penelitian untuk beberapa tahun kedepan dengan metode incremental, yaitu metode dengan pertumbuhan volume lalu lintas secara bertahap sehingga dapat ditentukan kapan dilakukan perubahan baik pada ruas jalan maupun simpang yang terdapat pada ruas tersebut, mengingat tingginya tingkat penggunaan ruas Jalan A.H Nasution sebagai jalan penghubung antara Bandung Barat dan Bandung Timur.

2. Perlu dilakukannya penelitian lebih lanjut mengenai perilaku pengemudi secara lebih detail, seperti average standstill distance, distance standing, dan distance driving.

3. Perlu dilakukannya penelitian pada situasi normal saat sedang tidak terjadi pandemi. 


\section{DAFTAR PUSTAKA}

E. Prahara dan H.Y Vermolen, 2018, The evaluation of traffic characteristic analyzed by Vissim (case study: underpass construction at Metro Pondok Indah Road), IOP Conf. Series: Earth and Eviromental Science.

Google Earth, 2020.

Kementerian Perhubungan, 2015, Peraturan Menteri Perhubungan Nomor: KM 96 Tahun 2015 tentang Pedoman Pelaksanaan Kegiatan Manajemen dan Rekayasa Lalu Lintas.

Pratama dan Elkhasnet, 2019, Analisis Kinerja Simpang Tak Bersinyal Jalan A.H. Nasution dan Jalan Cikadut, Kota Bandung, Jurnal Teknik Sipil ITENAS No. 2 Vol 5: 116-123.

Putri, Nurjanah., 2015, Mikrosimulasi Mixed Traffic pada Simpang Bersinyal dengan Perangkat Lunak Vissim (Studi Kasus: Simpang Tugu, Yogyakarta), Universitas Gajah Mada, Yogyakarta.

PTV Vision, 2019, PTV VISSIM 10 User Manual, PTV AG, Karlsruhe, Jerman.

Susilo, B.H., 2015, Rekayasa Lalu Lintas, Universitas Trisakti, Jakarta.

Susilo, B.H., 2017, Dasar-Dasar Rekayasa Transportasi, Universitas Trisakti, Jakarta.

Transportation Research Board, 2010, Highway Capacity Manual, HCM, Washington D.C.

Ulfah, Marissa., 2017, Mikrosimulasi Lalu Lintas Pada Simpang Tiga dengan Software Vissim, Universitas Hasanuddin, Makassar.

Wijaya, Hansen dan Susilo, B.H., 2020, Evaluasi Kinerja Operasi Simpang pada Jalan Pasir Kaliki Menggunakan Software Vissim, Jurnal Teknik Sipil, vol. 16, no 2, 2020, 134143. https://doi.org/10.28932/jts.v16i2.2385 